\title{
Intrinsic and extrinsic factors associated with falls in older adults: a case-control study in Mexico
}

\author{
Criselda Ríos-Fraustro, ${ }^{1}$ María E. Galván-Plata, ${ }^{2}$ Diana L. Gómez-Galicia, ${ }^{3}$ \\ Liliana Giraldo-Rodríguez, ${ }^{4}$ Marcela Agudelo-Botero ${ }^{5}$ and Dolores Mino-León ${ }^{6 *}$ \\ ${ }^{1}$ Faculty of Medicine, Universidad Nacional Autónoma de México, Mexico City; ${ }^{2}$ Health Research Coordination, Instituto Mexicano del Seguro Social, \\ Mexico City; ${ }^{3}$ Faculty of Pharmacy, Universidad Autónoma del Estado de Morelos, Cuernavaca, Morelos; ${ }^{4}$ nstituto Nacional de Geriatría, Secretaría \\ de Salud, Mexico City; ${ }^{5}$ Faculty of Medicine, Center of Research on Policies, Population and Health, Universidad Nacional Autónoma de México, \\ Mexico City; ${ }^{6}$ Clinical Epidemiology Research Unit, Specialty Hospital, Centro Médico Nacional Siglo XXI, Instituto Mexicano del Seguro Social, \\ Mexico City. Mexico
}

\begin{abstract}
Background: The literature refers that falls are of multifactorial origin, and some authors have proposed to classify risk factors as intrinsic and extrinsic. Objective: To estimate the risk of falls and their association with some intrinsic and extrinsic factors in older adults who receive medical care at the Mexican Institute of Social Security. Methods: Case-control study that included individuals of both genders aged $\geq 60$ years. Cases were patients who were admitted to the emergency department of a secondary care hospital diagnosed with injury or fracture secondary to a fall; the controls were patients who attended family medicine units. Descriptive, bivariate and multivariate statistical analysis was carried out. The SPSS program, version 22.0, was used. Results: Three-hundred and forty-two patients were included (171 cases and 171 controls). Mean age was $76.1 \pm$ 8.8 years, $66 \%$ were women and $97.1 \%$ had self-reported chronic diseases. Differences were observed in body mass index, in the proportion of cases with cognitive impairment, use of walking devices and dependence to perform basic and instrumental activities of daily living. Adjusted multivariate analysis revealed an association between the fall event and cognitive impairment and dependence to perform instrumental activities of daily living. Conclusions: Cognitive impairment and dependence to perform instrumental activities of daily living were associated with the risk of falling.
\end{abstract}

KEY WORDS: Falls. Older adult. Risk factors. Community-dwelling adults. Mexico.

\section{Factores intrínsecos y extrínsecos asociados con caídas en adultos mayores: estudio de casos y controles en México}

\section{Resumen}

Antecedentes: Las caídas tienen un origen multifactorial. Objetivo: Estimar el riesgo de caídas y su asociación con algunos factores intrínsecos y extrínsecos en adultos mayores. Métodos: Estudio de casos y controles que incluyó pacientes de ambos sexos con edades $\geq 60$ años. Los casos fueron pacientes que ingresaron al servicio de urgencias de un hospital de segundo nivel, con diagnóstico de lesión o fractura secundaria a una caída; los controles fueron pacientes que acudieron a unidades de medicina familiar. El análisis estadístico que se realizó fue descriptivo, bivariante y multivariante. Se utilizó el programa SPSS versión 22.0. Resultados: Se incluyeron 342 pacientes (171 casos y 171 controles). La edad promedio fue $76.1 \pm 8.8$ años, el $66 \%$ fueron mujeres y por autorreporte el $97.1 \%$ tenían enfermedades crónicas. Se observaron diferencias en el índice de masa corporal, en la proporción de casos con deterioro cognitivo, uso de dispositivos para caminar y

Correspondence:

*Dolores Mino-León

E-mail: minod_mx@yahoo.com
Gac Med Mex. 2021;157:127-132

Contents available at PubMed

www.gacetamedicademexico.com

0016-3813/C 2020 Academia Nacional de Medicina de México, A.C.. Published by Permanyer. This is an open access article under the CC BY-NC-ND license (http://creativecommons.org/licenses/by-nc-nd/4.0/). 
dependencia para realizar actividades básicas e instrumentales de la vida diaria. El análisis multivariante ajustado reveló asociación entre el evento caída con deterioro cognitivo y dependencia para realizar actividades instrumentales de la vida diaria. Conclusiones: El deterioro cognitivo y la dependencia para realizar actividades instrumentales de la vida diaria se asociaron al riesgo de caer.

PALABRAS CLAVE: Caídas. Adulto mayor. Factores de riesgo. Adultos que viven en comunidad. México.

\section{Background}

Different population-based studies have described the epidemiology of falls for older adults in different settings and, in these studies, lower rates have been reported to occur among community-living elderly people (0.3-1.6 per person annually), who are generally healthy, in comparison with people living in longterm care institutions, in whom rates are higher (0.6-3.6 per bed annually). In addition, differences between men and women and an increase in falls at older ages have been described.1.-3 $\mathrm{A}$ study carried out in the Americas region found that the proportion of older adults who suffered a fall per year ranged between $21.6 \%$ in Barbados and $34 \%$ in Chile, with the latter being followed by Mexico (33.5\%). ${ }^{4}$ According to the World Health Organization, a fall is defined as an event which results in a person coming to rest inadvertently on the ground or floor or other lower level. ${ }^{5}$ Falls, as well as the injuries they cause in older adults, are considered a global public health problem, due to their impact on the frequency of fractures, development of post-fall syndrome, hospitalization and mortality, among other complications; specifically, post-fall syndrome has been associated with confusion, immobilization, depression and loss of autonomy. ${ }^{6-9}$ The literature refers that falls have a multifactorial origin, ${ }^{6}$ and some authors have proposed for risk factors to be classified as intrinsic and extrinsic. Intrinsic factors are related to the functional and health status of the individual (comorbidities, functional disability, gait and balance alterations, and problems for carrying out activities of daily living) and extrinsic factors include the use of medications (polypharmacy, potentially inappropriate prescribing [PIP] and specific therapeutic groups), use of prostheses and walking aids, and environmental conditions (poor lighting and lack of safety equipment in the bathroom, among others). ${ }^{10-13}$ The purpose of this study was to estimate the risk of suffering a fall associated with some intrinsic (clinical and functional conditions) and extrinsic factors (medications and use of walking aids) in a sample of older adults who are provided medical care at the Mexican
Institute of Social Security (IMSS - Instituto Mexicano del Seguro Social).

\section{Material and Methods}

\section{Study design and sample}

A case-control study was carried out, which included patients of both genders aged $\geq 60$ years. To calculate the sample size, a $95 \%$ confidence level, $80 \%$ power and a case: control ratio of 1:1 were used. The study was conducted from November 2014 to August 2015.

\section{Case and control definition}

A case was defined as that person who as a result of an event involuntarily fell from his/her height to the ground. Cases were systematically captured at the emergency department of an IMSS regional general hospital in Mexico City, with a diagnosis of injury and/ or fracture secondary to a fall. Cases in which the fall was secondary to a traffic accident or intentional, when by self-report or by information provided by the accompanying family member the case was known to have sustained one or more falls within the six months prior to current admission, or if the subject suffered from positional vertigo, labyrinthitis, or vertebrobasilar insufficiency, or if he/she would not take his medications on a chronic basis, were excluded. The controls were recruited at the family medicine unit (UMF) where the case attended for first-contact medical attention and were matched by age and gender; controls with a fall documented on their medical records within six months prior to the date of being selected were excluded. All patients signed an informed consent letter.

\section{Variables}

- Sociodemographic: age, gender, level of education (basic, $\leq 10$ years, and higher education, > 10 years), productivity in terms of work and living alone. 
- Intrinsic variables:

- Clinical: body mass index (BMI), visual impairment (blindness, myopia, astigmatism, hyperopia, glaucoma and cataracts); cognitive impairment $(\leq 23$ score in the Mini-Mental State Examination [MMSE] $: ;^{14}$ number of chronic diseases and alcoholism (consumption at least once weekly).

- Functionality: basic activities of daily living (BADL) evaluated with the Katz index ${ }^{15}$ and instrumental activities of daily living (IADL), according to Lawton and Brody Scale. ${ }^{16}$

- Extrinsic variables:

- Medications: number of drugs used for the treatment of chronic conditions, polypharmacy ( $\geq 5$ drugs), PIP according to Beers' criteria and with the Screening Tool of Older Persons' Prescriptions (STOPP); ${ }^{17,18}$ fall risk-increasing drugs (FRID), which include: a) cardiovascular agents (metoprolol, propranolol, captopril, enalapril, lisinopril, ramipril, amlodipine, felodipine, nifedipine, verapamil, prazosin, hydralazine, hydrochlorothiazide, and furosemide); b) drugs with anticholinergic effect (ipratropium bromide, tiotropium bromide, oxybutynin, atropine, imipramine, amitriptyline and diphenhydramine); c) neuroleptics/antipsychotics (levomepromazine, trifluoperazine, haloperidol, flupentixol, ziprasidone, clozapine, olanzapine, quetiapine, risperidone), and d) hypnotics and sedatives (alprazolam, lorazepam, bromazepam and diazepam).

- Use of walking aids (cane, walker, crutches, and wheelchair).

\section{Data collection}

Every day, one of the investigators (RFC) reviewed the clinical notes of patients who had been admitted to the emergency department in order to identify those cases that met the inclusion criteria; once a case agreed to participate in the study, signing of the informed consent letter was requested and initial questionnaire was administered (sociodemographic data, medical and pharmacological history [six months prior to having suffered the fall], visual problems and alcohol consumption); the Katz index questionnaire, the Lawton and Brody scale and the MMSE were also applied. The latter evaluation was carried out if patient health status allowed; if not, it was postponed until patient clinical condition improved.
To recruit the controls, two researchers (RFC, GGDL) attended the UMF where the case received first-contact medical care in order to review the records and identify a patient of the same gender and age as the case; once a control subject was identified, he/she was contacted by phone to invite him/her, and an appointment at the UMF was scheduled. During the appointment, the control subject was asked to sign the informed consent letter, and was applied the data collection instruments and scales that were applied to the case.

\section{Statistical analysis}

For continuous variables, the mean \pm standard deviation were used, and for categorical variables, frequencies and percentages. Contrast tests were applied (Pearson's chi-square test and Student's t-test for independent samples). Logistic regression models (simple and adjusted for sociodemographic variables) were used to estimate the risk of falling associated with intrinsic and extrinsic factors (odds ratios [OR] and $95 \%$ confidence intervals [Cl]). The level of statistical significance used in all tests was $p<0.05$. SPSS statistical package, version 22.0 (SPSS Inc., Chicago, IL) for Windows, was used.

\section{Results}

Three hundred and forty-two adults (171 cases and 171 controls) aged $\geq 60$ years were included. Mean age was $76.1 \pm 8.8$ years; $66 \%$ were women and $97.1 \%$ reported suffering from at least one chronic disease, with the most common being hypertension (67\%), type 2 diabetes mellitus (36\%), gastritis (24\%), dyslipidemia (13\%) and degenerative joint disease $(11 \%)$. The drugs referred to with the highest frequency of consumption were vitamin B12 (B03BA), antihypertensive drugs (C09CA01 and C09AA02), hypoglycemic agents (A10BA02) and anti-inflammatory and analgesic drugs (N02BA01 and N02BE01).

No differences were observed in the bivariate analysis (cases vs. controls) for the level of education, having work activities and living alone. As for clinical variables, average BMI was observed to be lower in cases than in controls, and a higher proportion of cases were found to have cognitive impairment $(p<0.05)$. Regarding functionality, a higher proportion of cases had dependence for carrying out BADL and IADL, with the differences being significant. No significant differences were observed in the number of drugs, in the 
Table 1. Controls and cases characteristics

\begin{tabular}{|c|c|c|c|}
\hline Variables & $\begin{array}{c}\text { Controls } \\
n=171 \\
n(\%)\end{array}$ & $\begin{array}{c}\text { Cases } \\
n=171 \\
n(\%)\end{array}$ & p \\
\hline $\begin{array}{l}\text { Sociodemographic variables } \\
\text { Age (years)* }\end{array}$ & $75.7 \pm 8.5$ & $76.4 \pm 9.0$ & 0.450 \\
\hline $\begin{array}{l}\text { Gender } \\
\text { Females } \\
\text { Males }\end{array}$ & $\begin{array}{l}113(66.1) \\
58(33.9)\end{array}$ & $\begin{array}{l}113(66.1) \\
58(33.9)\end{array}$ & 1.000 \\
\hline $\begin{array}{l}\text { Level of education } \\
\text { Basic } \leq 10 \text { years }\end{array}$ & $129(75.4)$ & $131(76.6)$ & 0.450 \\
\hline Productive in terms of work (yes) & $9(5.3)$ & $15(8.8)$ & 0.145 \\
\hline Lives alone (yes) & $31(18.1)$ & $21(12.3)$ & 0.087 \\
\hline $\begin{array}{l}\text { Clinical variables } \\
\text { Body mass index } \\
\text { Visual impairment } \\
\text { Cognitive impairment }{ }^{\dagger} \\
\text { Number of chronic diseases } \\
\text { Alcoholism (yes) }\end{array}$ & $\begin{array}{l}25.5 \pm 6.7 \\
141(82.5) \\
21(12.3) \\
2.7 \pm 1.4 \\
20(11.7)\end{array}$ & $\begin{array}{l}24.1 \pm 7.0 \\
149(87.1) \\
50(39.9) \\
2.9 \pm 1.6 \\
28(16.4)\end{array}$ & $\begin{array}{l}0.041 \\
0.146 \\
0.000 \\
0.077 \\
0.138\end{array}$ \\
\hline $\begin{array}{l}\text { Functionality } \\
\text { Dependence for BADL } \\
\text { Dependence for IADL }\end{array}$ & $\begin{array}{l}19(11.1) \\
76(44.4)\end{array}$ & $\begin{array}{c}40(23.4) \\
135(78.9)\end{array}$ & $\begin{array}{l}0.002 \\
0.000\end{array}$ \\
\hline $\begin{array}{l}\text { Medications } \\
\text { Number of drugs* } \\
\text { Polypharmacy }{ }^{\ddagger} \\
\text { Beers PIP } \\
\text { STOPP PIP } \\
\text { FRID }\end{array}$ & $\begin{array}{c}5 \pm 3 \\
91(53.2) \\
53(31.0) \\
67(39.2) \\
122(71.3)\end{array}$ & $\begin{array}{c}5 \pm 3 \\
94(55.0) \\
58(33.9) \\
74(43.3) \\
128(74.9)\end{array}$ & $\begin{array}{l}0.638 \\
0.828 \\
0.644 \\
0.510 \\
0.542\end{array}$ \\
\hline $\begin{array}{l}\text { Other } \\
\text { Use of walking aids }\end{array}$ & $47(27.5)$ & $69(40.4)$ & 0.008 \\
\hline $\begin{array}{l}\text { PIP = potentially inappropriate prescribing; } \\
\text { prescriptions; FRID }=\text { fall risk-increasing dru } \\
{ }^{*} \text { Average } \pm \text { standard deviation. } \\
{ }^{+} \text {Mini-Mental State Evaluation } \leq 23 . \\
\neq \geq 5 \text { drugs. }\end{array}$ & $P=$ screenir & ol of older $\mathrm{p}$ & \\
\hline
\end{tabular}

proportions of polypharmacy and PIP according to Beers, STOPP and FRID criteria. Finally, the proportion of subjects that used walking aids was higher in cases than in controls $(p=0.008)$ (Table 1).

ORs showed that BMI, cognitive impairment, functional dependence (BADL and IADL) and use of walking aids were variables that were associated with the risk of falling (Table 2). Finally, the adjusted multivariate model showed that cognitive impairment and dependence for IADL were variables that maintained a significant association with the risk of falling (Table 3 ).

\section{Discussion}

The literature refers that falls have a multifactorial origin, and classifying the risk factors associated with
Table 2. Simple regression model

\begin{tabular}{|c|c|c|}
\hline Risk factor & OR $(95 \% \mathrm{Cl})$ & $p$ \\
\hline $\begin{array}{l}\text { Level of education } \\
\text { (reference: > } 10 \text { years) } \\
\leq 10 \text { years }\end{array}$ & $1.066(0.649-1.752)$ & 0.800 \\
\hline $\begin{array}{l}\text { Productive in terms of work } \\
\text { (reference: yes) } \\
\text { No }\end{array}$ & $0.578(0.246-1.359)$ & 0.209 \\
\hline $\begin{array}{l}\text { Lives alone (reference: no) } \\
\text { Yes }\end{array}$ & $0.632(0.347-1.152)$ & 0.134 \\
\hline Body mass index & 0.967 (0.936-0.999) & 0.044 \\
\hline $\begin{array}{l}\text { Visual impairment (reference: no) } \\
\text { Yes }\end{array}$ & $1.441(0.794-2.616)$ & 0.230 \\
\hline $\begin{array}{l}\text { Cognitive impairment* (reference: no) } \\
\text { Yes }\end{array}$ & $3.189(1.812-5.613)$ & 0.000 \\
\hline Number of chronic diseases & $1.132(0.986-1.300)$ & 0.078 \\
\hline $\begin{array}{l}\text { Alcoholism (reference: no) } \\
\text { Yes }\end{array}$ & $1.478(0.797-2.742)$ & 0.215 \\
\hline $\begin{array}{l}\text { Dependence for BADL (reference: no) } \\
\text { Yes }\end{array}$ & $2.443(1.349-4.424)$ & 0.003 \\
\hline $\begin{array}{l}\text { Dependence for IADL (reference: no) } \\
\text { Yes }\end{array}$ & 4.668 (2.913-7.542) & 0.000 \\
\hline $\begin{array}{l}\text { Polypharmacy }{ }^{\dagger} \text { (reference: no) } \\
\text { Yes }\end{array}$ & $1.073(0.701-1.642)$ & 0.745 \\
\hline $\begin{array}{l}\text { Beers PIP (reference: no) } \\
\text { Yes }\end{array}$ & $1.143(0.726-1.798)$ & 0.564 \\
\hline $\begin{array}{l}\text { STOPP PIP (reference: no) } \\
\text { Yes }\end{array}$ & $1.184(0.770-1.822)$ & 0.442 \\
\hline $\begin{array}{l}\text { FRID (reference: no) } \\
\text { Yes }\end{array}$ & $1.196(0.741-1.930)$ & 0.465 \\
\hline $\begin{array}{l}\text { Use of walking aids (reference: no) } \\
\text { Yes }\end{array}$ & $1.785(1.134-2.810)$ & 0.012 \\
\hline $\begin{array}{l}\text { OR }=\text { odds ratio; } \mathrm{Cl}=\text { confidence interval; } \mathrm{BADL}=\text { b } \\
\text { IADL }=\text { instrumental activities of daily living; } \mathrm{PIP}=\text { pot } \\
\text { STOPP = screening tool of older persons' prescription } \\
{ }^{*} \text { Mini-Mental State Examination } \leq 23 \text {. } \\
+\geq 5 \text { drugs. }\end{array}$ & $\begin{array}{l}\text { asic activities of daily living; } \\
\text { tentially inappropriate prescril } \\
n s ; F R I D=\text { fall risk-increasing }\end{array}$ & $\begin{array}{l}\text { bing; } \\
\text { drugs. }\end{array}$ \\
\hline
\end{tabular}

this event as intrinsic and extrinsic has been proposed. ${ }^{10,19}$ In this study, intrinsic factors (cognitive impairment and dependence for IADL) were the variables that were associated with the risk of falling; other studies that analyzed different populations have reported similar results. ${ }^{20-22}$ In addition, people with balance problems and difficulty to carry out executive functions (EF) have been documented to have a higher risk of falling. ${ }^{20}$ Another study reported an association with mild cognitive impairment (based mainly on EF alterations) with an increased risk of falling, ${ }^{21}$ and the results of a longitudinal study that included Mexico 
Table 3. Multiple logistic regression model adjusted for sociodemographic variables

\begin{tabular}{|c|c|c|}
\hline Risk factor & OR $(95 \% \mathrm{Cl})$ & p \\
\hline Education $\leq 10$ years & $0.788(0.447-1.386)$ & 0.408 \\
\hline Productive in terms of work & $0.542(0.208-1.414)$ & 0.211 \\
\hline Lives alone & $0.878(0.440-1.750)$ & 0.711 \\
\hline Body mass index & $0.967(0.932-1.002)$ & 0.064 \\
\hline Cognitive impairment* & $2.071(1.106-3.877)$ & 0.023 \\
\hline Dependence for BADL & $1.067(0.519-2.197)$ & 0.859 \\
\hline Dependence for IADL & $3.786(2.216-6.469)$ & 0.000 \\
\hline Use of walking aids & $0.974(0.556-1.706)$ & 0.926 \\
\hline
\end{tabular}

detected an association between cognitive impairment and the risk of falling. ${ }^{23}$ On the other hand, people with dementia have been reported to experience higher gait instability when contrasted with people without dementia, which has been attributed to the presence of alterations at the cortical level and, specifically, EF deterioration. ${ }^{24-27} \mathrm{EFs}$ are a series of higher cognitive processes that use and modify information from various sensory systems at the cortical level, located at anterior and posterior regions of the brain..$^{28,29}$ These integrative functions are necessary to effectively carry out actions aimed at achieving a goal and maintaining attention. Therefore, these functions have been suggested to be the basis for an individual to be able to independently carry out activities of daily living, ${ }^{30,31}$ and their decline affects the ability to efficiently and safely walk. ${ }^{28,29,32}$

Limitations of the study include the lack of an analysis of gait characteristics and vestibular problems and information on the falls, in addition to a limited number of controls. However, the study has strengths, since recall bias was avoided by including incident cases, controls were matched with cases with regard to biological variables (age and gender) and were extracted from the same population cases originate from, and thus they had the same chance of having been exposed to the same risk factors. Another strength of the study is that the impact of medications (polypharmacy, PIP according to Beers, STOPP and FRID criteria) on falls was explored, which is important, given that previous studies carried out in Mexico have not analyzed it, ${ }^{33,34}$ and if we consider that the pattern of medicine consumption may be different between countries, medication analysis becomes relevant; for example, similarity has been described in the consumption patterns between Mexico and Brazil, ${ }^{35}$ not so in comparison with European countries, where hypnotics, sedatives and anxiolytics are the drugs that are most often reported as PIP, while, in Mexico, non-steroidal anti-inflammatory drugs and glibenclamide prescription are. ${ }^{36}$

The results of this study reveal an important challenge on which IMSS must act, and it is related to the need to implement systematic geriatric evaluation at primary care, since IMSS is the institution that provides medical services to $40.6 \%$ of older adults ( $\geq 60$ years of age) in the country. ${ }^{37}$ This action would allow identifying the population at risk ${ }^{38}$ that could benefit from timely actions that have shown a positive impact on cognition $^{39}$ and, in turn, reduce the risk of falls.

\section{Conclusions}

The study results indicate that older adults with cognitive impairment and dependence for IADL have a higher risk of falling, which is consistent with the relationship described between EF deficit and falls, and these results open the possibility of detecting EFs early alterations and starting treatment to improve them and, consequently, reduce the risk of falling.

\section{Acknowledgments}

To IMSS Mexico City South Delegation authorities; to Regional General Hospital No. 2 director, Dr. Miguel Chávez Covarrubias; to HGR No. 2 Education and Research clinical coordinator. To doctors Guillermo Alejandro Salas Morales and Luis Alberto Guízar García, from HGR No. 2 Internal Medicine Department, as well as to UMFs number 7, 10, 15, 19, 43 and 46 authorities, for their support for carrying out this research. To Professor Albert Figueras Suñé, for his suggestions.

\section{Conflict of interests}

The authors declare that they have no conflicts of interest.

\section{Funding}

Instituto Nacional de Geriatría, Secretaría de Salud, Mexico. 


\section{Ethical disclosures}

Protection of human and animal subjects. The authors declare that no experiments were performed on humans or animals for this research.

Confidentiality of data. The authors declare that they have followed the protocols of their work center on the publication of patient data.

Right to privacy and informed consent. The authors have obtained informed consent from the patients and/or subjects referred to in the article. This document is in the possession of the corresponding author.

\section{References}

1. Rubenstein LZ. Falls in older people: epidemiology, risk factors and strategies for prevention. Age Ageing. 2006;35(Suppl 2):ii37-ii41.

2. Peel NM, Kassulke DJ, McClure RJ. Population based study of hospitalised fall related injuries in older people. Inj Prev. 2002;8:280-3.

3. Stalenhoef PA, Diederiks JP, Knottnerus JA, Kester AD, Crebolder HF. A risk model for the prediction of recurrent falls in community-dwelling elderly: a prospective cohort study. J Clin Epidemiol. 2002;55:1088-94.

4. Reyes-Ortiz CA, Al Snih S, Markides KS. Falls among elderly persons in Latin America and the Caribbean and among elderly Mexican-Americans. Rev Panam Salud Publica. 2005;17:362-9.

5. Falls [Internet]. World Health Organization; January 16, 2018 [accessed May 30, 2018]. Available at: http://www.who.int/es/news-room/factsheets/detail/falls

6. WHO Global Report on Falls Prevention in Older Age [Internet]. Geneva, Switzerland: World Health Organization; 2007. Available at: https://extranet.who.int/agefriendlyworld/wp-content/uploads/2014/06/WHo-Globalreport-on-falls-prevention-in-older-age.pdf

7. Espino DV, Palmer RF, Miles TP, Mouton CP, Wood RC, Bayne NS, et al. Prevalence, incidence, and risk factors associated with hip fractures in community-dwelling older Mexican Americans: results of the Hispanic EPESE study. Establish Population for the Epidemiologic Study for the Elderly. J Am Geriatr Soc. 2000;48:1252-60.

8. Kannus P, Niemi S, Palvanen M, Parkkari J. Fall-induced injuries among elderly people. Lancet. 1997;350:1174.

9. Kempen GI, van Haastregt JC, McKee KJ, Delbaere K, Zijlstra GA. Socio-demographic, health-related and psychosocial correlates of fear of falling and avoidance of activity in community-living older persons who avoid activity due to fear of falling. BMC Public Health. 2009;9:170.

10. Huang AR, Mallet L, Rochefort CM, Eguale T, Buckeridge DL, Tamblyn R. Medication-related falls in the elderly: causative factors and preventive strategies. Drugs Aging. 2012;29:359-76.

11. Tinetti ME, Baker DI, McAvay G, Claus EB, Garrett P, Gottschalk M, et al. A multifactorial intervention to reduce the risk of falling among elderly people living in the community. N Engl J Med. 1994;331:821-7.

12. Hosseini $H$, Hosseini $N$. Epidemiology and prevention of fall injuries among the elderly. Hosp Top. 2008;86:15-20.

13. Guelich MM. Prevention of falls in the elderly: a literature review. Top Geriatr Rehabil. 1999;15:15-25.

14. Folstein MF, Folstein SE, McHugh PR. "Mini-mental state". A practical method for grading the cognitive state of patients for the clinician. J Psychiatr Res. 1975;12:189-98.

15. Katz S, Ford AB, Moskowitz RW, Jackson BA, Jaffe MW. Studies of illness in the aged. The Index of Adl: A standardized measure of biological and psychosocial function. JAMA. 1963;185:914-9.

16. Lawton MP, Brody EM. Assessment of older people: self-maintaining and instrumental activities of daily living. Gerontologist. 1969;9:179-86.
17. American Geriatrics Society Beers Criteria Update Expert Panel. American Geriatrics Society 2015 Updated Beers Criteria for Potentially Inappropriate Medication Use in Older Adults. J Am Geriatr Soc. 2015; 63:2227-46.

18. O'Mahony D, O'Sullivan D, Byrne S, O'Connor MN, Ryan C, Gallagher P. STOPP/START criteria for potentially inappropriate prescribing in older people: version 2. Age Ageing. 2015;44:213-8.

19. Santillana-Hernández SP, Alvarado-Moctezuma LE, Medina-Beltran GR, Gómez-Ortega G, Cortés-González RM. Caídas en el adulto mayor factores intrínsecos y extrínsecos. Rev Med Inst Mex Seguro Soc. 2002;40:489-93.

20. Delbaere K, Kochan NA, Close JC, Menant JC, Sturnieks DL, Brodaty H, et al. Mild cognitive impairment as a predictor of falls in community-dwelling older people. Am J Geriatr Psychiatry. 2012;20:845-53.

21. Delbaere K, Close JC, Heim J, Sachdev PS, Brodaty H, Slavin MJ, et al. A multifactorial approach to understanding fall risk in older people. J Am Geriatr Soc. 2010;58:1679-85.

22. Holtzer R, Friedman R, Lipton RB, Katz M, Xue X, Verghese J. The relationship between specific cognitive functions and falls in aging. Neuropsychology. 2007;2:540-8.

23. Stewart-Williams J, Kowal P, Hestekin H, O'Driscoll T, Peltzer K, Yawson A, et al. Prevalence, risk factors and disability associated with fall-related injury in older adults in low- and middle-income countries: results from the WHO Study on global AGEing and adult health (SAGE). BMC Med. 2015;13:147.

24. Allali G, Assal F, Kressig RW, Dubost V, Herrmann FR, Beauchet O. Impact of impaired executive function on gait stability. Dement Geriatr Cogn Disord. 2008;26:364-9.

25. Beauchet O, Kressig RW, Najafi B, Aminian K, Dubost V, Mourey F. Age-related decline of gait control under a dual-task condition. J Am Geriatr Soc. 2003;51:1187-8.

26. Verghese J, Lipton RB, Hall CB, Kuslansky G, Katz MJ, Buschke H. Abnormality of gait as a predictor of non-Alzheimer's dementia. N Engl J Med. 2002;347:1761-8

27. Waite LM, Grayson DA, Piguet O, Creasey H, Bennett HP, Broe GA. Gait slowing as a predictor of incident dementia: 6-year longitudinal data from the Sydney Older Persons Study. J Neurol Sci. 2005;229-230:89-93.

28. Fuster JM. Frontal lobe and cognitive development. J Neurocytol. 2002;31:373-85

29. Goethals I, Audenaert K, van de Wiele C, Dierckx R. The prefrontal cortex: insights from functional neuroimaging using cognitive activation tasks. Eur J Nucl Med Mol Imaging. 2004;31:408-16.

30. Romero-Ayuso DM. Actividades de la vida diaria. An Psicol. 2007;23:264-71.

31. Reppermund S, Brodaty H, Crawford JD, Kochan NA, Draper B, Slavin MJ, et al. Impairment in instrumental activities of daily living with high cognitive demand is an early marker of mild cognitive impairment: the Sydney memory and ageing study. Psychol Med. 2013:43:2437-45.

32. Yogev-Seligmann G, Hausdorff JM, Giladi N. The role of executive function and attention in gait. Mov Disord. 2008;23:329-42;quiz 472.

33. Agudelo-Botero M, Giraldo-Rodríguez L, Murillo-González JC Mino-León D, Cruz-Arenas E. Factors associated with occasional and recurrent falls in Mexican community-dwelling older people. PLoS One. 2018:13:e0192926.

34. Valderrama-Hinds LM, Al Snih S, Chen NW, Rodriguez MA, Wong R. Falls in Mexican older adults aged 60 years and older. Aging Clin Exp Res. 2018;30:1345-51.

35. Oliveira MG, Amorim WW, de Jesus SR, Heine JM, Coqueiro HL,Passos LC. A comparison of the Beers and STOPP criteria for identifying the use of potentially inappropriate medications among elderly patients in primary care. J Eval Clin Pract. 2015;21:320-5.

36. Mino-León D, Sánchez-García S, Giraldo-Rodríguez L, Reyes-Morales H. Potentially inappropriate prescribing to older adults in ambulatory care: prevalence and associated patient conditions. Eur Geriatr Med. 2019;10:639.

37. Manrique-Espinoza B, Salinas-Rodríguez A, Moreno-Tamayo KM, Acosta-Castillo I, Sosa-Ortiz AL, Gutierrez-Robledo LM, et al. Condiciones de salud y estado funcional de los adultos mayores en México. Salud Publica Mex. 2013;55(Suppl 2):S323-31.

38. Mirelman A, Herman T, Brozgol M, Dorfman M, Sprecher E, Schweiger A, et al. Executive function and falls in older adults: new findings from a five-year prospective study link fall risk to cognition. PLoS One. 2012;7:e40297.

39. Colcombe SJ, Kramer AF, McAuley E, Erickson KI, Scalf P. Neurocognitive aging and cardiovascular fitness: recent findings and future directions. J Mol Neurosci. 2004;24:9-14. 